\title{
ANALISIS PERILAKU BELAJAR SISWA DALAM PERSPEKTIF NEUROPSIKOLOGI DI PAUD PELITA GUNUNGPUYUH KOTA SUKABUMI JAWA BARAT
}

\author{
Aeni Latifah ${ }^{1}$, Dadang Sahroni ${ }^{2}$ \\ ${ }^{1}$ Program Studi Pendidikan Agama Islam STAI Sukabumi \\ ${ }^{2}$ Program Studi Pendidikan Agama Islam STAI Sukabumi \\ Email: aenilatifah@gmail.com
}

(Received: November 2018; Accepted: November 2018; Published: Desember 2018)

\begin{abstract}
The purpose of this study is to analyze student learning difficulties in a neuropsychological perspective. The approach of this research is quantitative descriptive. Data was collected through library studies. The source of information is the City Library of Sukabumi. Based on understanding, study and descriptive analysis, in this study it was found that the factors that influence student achievement in PELITA Gunungpuyuh PAUD, Sukabumi City so that it is suspected to be the cause of Minimal Brain Disfunction (DMO) are: 1) Trauma, which is very external trauma, from the worst (car crash) to the lightest (falling from the bed). There are 3 terms for trauma to the brain, namely concussion (concussion), cerebral hemorrhage (contusion), and torn brain (laceration); 2) Vascular accidents, namely the occurrence of blockage or rupture of the cerebral blood vessels; 3) Tumors, tumors in the brain, symptoms that appear sometimes seem mild (headaches, impaired vision), but if they do, the consequences can be fatal; 4) Degenerative diseases, namely diseases that cause deterioration, such as Alzheimer's dementia, etc.; 5) Nutritional deficiencies (malnutrition); 6) Poisoning, which can cause a person to delirium (delirium).
\end{abstract}

Keywords: Learning Difficulties, Neuropsychology, Minimal Brain Dysfunction

\begin{abstract}
ABSTRAK
Tujuan dari penelitian ini adalah untuk menganalisis kesulitan-kesulitan belajar siswa dalam perspektif neuropsikologi. Pendekatan penelitian ini adalah deskriptif kuantitatif. Data dikumpulkan melalui studi kepustakaan. Sumber informasi adalah Perpustakaan Kota Sukabumi. Berdasarkan pemahaman, kajian dan analisis deskriptif, dalam penelitian ini ditemukan bahwa faktor-faktor yang mempengaruhi prestasi belajar siswa di PAUD PELITA Gunungpuyuh, Kota Sukabumi sehingga diduga menjadi penyebab Disfungsi Minimal Otak (DMO) adalah: 1) Trauma, yang dimaksud dengan trauma sangat luar, mulai paling parah (tabrakan mobil) hingga yang paling ringan (jatuh dari tempat tidur). Ada 3 istilah untuk trauma pada otak, yaitu gegar otak (concussion), pendarahan otak (contusion), dan robek otak (laceration); 2) Vascular accidents, yaitu terjadinya penyumbatan atau pecahnya pembuluh darah otak; 3) Tumor, tumor di otak, gejala yang ditampil kadang-kadang terkesan ringan (sakit kepala, gangguan penglihatan), tapi kalau memang ada, akibatnya dapat fatal; 4) Penyakit degeneratif, yaitu penyakit yang menyebabkan terjadinya kemunduran, misalnya dementia jenis Alzheimer, dan lain-lain; 5) Defisiensi nutrisi (kurang gizi); 6) Keracunan, yang dapat menyebabkan seseorang mengigau (delirium).
\end{abstract}

Kata Kunci: Kesulitan Belajar, Neuropsikologi, Disfungsi Minimal Otak

\section{PENDAHULUAN}

Belajar sering diartikan adanya perubahan pada diri seseorang atau peserta didik dari tidak tahu menjadi tahu, dari tidak bisa menjadi bisa, dan perubahan tersebut terjadi pada aspek pengetahuan, keterampilan, dan sikap. "Belajar adalah seperangkat proses kognitif yang mengubah sifat stimulasi lingkungan, melewati pengolahan informasi, menjadi kapabilitas baru" (Dimyati dan Mudjiono, 2009).

Dilihat dari psikologi, belajar adalah adanya perubahan kematangan bagi anak didik sebagai akibat belajar sedangkan dilihat dari proses adalah adanya interaksi antara peserta didik dengan pendidik sebagai proses pembelajaran, dan perubahan ini termasuk 
perubahan tingkah laku yang dipengaruhi oleh ilmu pengetahuan yang diperolehnya dari proses belajar. (Syaiful Sagala, 2006)

Aktivitas belajar berikut hasil-hasilnya dalam pelaksanaannya tidak semudah apa yang dibayangkan, tidak sedikit guru mengalami berbagai kesulitan belajar yang dihadapinya. Seperti guru mengalami kesulitan memfokuskan perhatian peserta didiknya terhadap mata pelajaran yang sedang disampaikannnya. "Perhatian merupakan pemusatan atau konsentrasi dari seluruh aktivitas individu yang ditunjukan kepada suatu objek atau sekumpulan objek" (Bimo Walgito, 1989). Kesulitan lainnya adalah berkaitan dengan motivasi dan minat belajar, serta lingkungan belajar yang tidak kondusif dan lain sebagainya.

Belajar selalu dilihat dari prestasi yang diraih oleh setiap peserta didik, apabila peserta didik dalam kegiatan belajarnya mencapai standar minimal yang telah ditetapkan oleh guru maka peserta didik tersebut dapat dikatakan memiliki prestasi baik, bahkan prestasi itu dikatakan tinggi jika peserta didik melampaui batas minimal yang telah ditetapkan oleh guru. Untuk memperoleh hasil belajar yang baik dan memiliki prestasi yang baik pula, maka dalam kegiatan belajar mengajar setiap guru hendaknya dapat memenuhi syarat belajar agar peserta didik dapat berhasil dalam belajarnya.

Sejatinya belajar di sekolah selalu berdampingan dengan prestasi yang diraih oleh setiap peserta didik. Namun pada realitanya belajar di sekolah prestasi yang diraih oleh setiap peserta didik tidak selalu demikian.

Rendahnya prestasi di atas tidak lepas dari rendahnya prestasi pada setiap satuan lembaga pendidikan yang memberikan kontribusi secara komulatif terhadap prestasi belajar pada tingkat nasional. Penyebab rendahnya prestasi disinyalir kegiatan belajar pada setiap satuan pendidikan yang kurang berhasil bahkan tidak berhasil. Ketidak berhasilan belajar di sekolah secara khusus disebabkan oleh adanya kesulitan belajar yang tidak tertanggulangi secara baik.
Fenomena perilaku ketidakpedulian dalam belajar, lamban dalam mengerjakan tugas, menunjukkan perilaku menyimpang dan tidak biasa dilakukan, merupakan bagian dari kesulitan belajar siswa di PAUD PELITA, Gunungpuyuh, Kota Sukabumi. Penelitian ini akan mengkaji dan menganalisis kesulitankesulitan belajar siswa dalam perspektif neuropsikologi yang berkaitan dengan perkembangan otak siswa PAUD PELITA, Gunungpuyuh, Kota Sukabumi.

\section{METODE}

Pendekatan yang digunakan dalam penelitian ini adalah penelitian kualitatif. Penelitian kualitatif merupaka prosedur penelitian yang menghasilkan data deskriptif melalui pengungkapan kata-kata tertulis atau lisan dari orang-orang, peristiwa tertentu secara rinci dan mendalam serta perilaku yang dapat diamati (C.R. Bogdan \& S.J Taylor, 1993). Jenis penelitian ini adalah studi analisis deskriptif. Studi analisis deskriptif dipilih karena pendekatan ini membuat peneliti dapat mudah memperoleh hasil kajian dan analisis yang terintegrasi mengenai interrelasi berbagai fakta dan dimensi dari studi analisis deskriptif tersebut (Poerwandari, 2009).

Sumber data utama dalam penelitian ini adalah buku-buku literatur dan website tentang pendidikan anak usia dini yang anaknya mengalami kesulitan belajar di sekolah. Teknik pengumpulan data yang digunakan dalam penelitian ini adalah penelitian deskriptif dan studi kepustakaan. Dalam penelitian kuantitatif, teknik pengumpulan data yang utama adalah bukubuku literatur dan website.

Langkah-langkah yang akan dilakukan dalam proses pengelolaan data adalah:

a. Kategorisasi, yaitu mengumpulkan datadata berdasarkan kategori-kategori tertentu seperti dokumen, sosial budaya, pendidikan, dan lain-lain.

b. Tipologisasi, yaitu mengelompokkan datadata berdasarkan pola-pola tertentu berdasarkan pendapat, pemikiran, dan 
kriteria tertentu (tradisional, modern dan lain-lain).

c. Mengedit data yang kegunaannya mengoreksi dan mengecek kembali datadata yang sudah terkumpul agar tidak terjadi kesalahan dan tumpang tindih pembahasan.

Sedangkan kajian dan analisis data yang digunakan dalam penelitian ini adalah deskriptif-analisis. Dalam hal ini, tampilan data yang dihasilkan dari paparan-paparan subyek penelitian yang diperoleh dari studi kepustakaan. Dari hasil data-data deskriptif tersebut, kemudian dikaji dan dianalisis dengan tujuan menemukan pemahaman yang lebih utuh dan komprehensif.

Langkah selanjutnya peneliti membuat deskripsi, analisis dan memaknai data dan informasi dalam bentuk simpulan-simpulan penting dari penelitian ini. Dalam perspektif subjektif peneliti, hasil penelitian ini memiliki distinsi dan diferensi, sesuatu yang berbeda dengan penelitian sebelumnya.

\section{KAJIAN PUSTAKA}

Pengertian Neuropsikologi

Neuropsikologi adalah suatu ilmu yang mempelajari hubungan antara otak dan perilaku, disfungsi otak dan perilaku, dan melakukan assesmen dan treatment untuk perilaku dengan fungsi otak yang terganggu. Sedangkan asesmen neuropsikologis adalah sebuah metode untuk menggambarkan fungsi otak berdasarkan pada performance pasien melalui test-test yang distandarisasi, yang telah terbukti memiliki indikator akurat mengenai hubungan otak perilaku.

Dalam lima tahun

terakhir, neuropsikologi berkembang pesat. Ini terlihat dari jumlah anggota asosiasi Neuropsikologi, program pelatihan, makalah-makalah yang dipublikasikan, dan posisi-posisi tugas berkaitan dengan Neuropsikologi di Amerika Serikat yang meningkat (Phares 1992).

Sebagai ilmu, Neuropsikologi dianggap sebagai salah satu bagian dari Biopsikologi. Bidang lain yang termasuk dalam biopsikologi antara lain; psikologi faal, psikofisiologi, dan psikologi perbandingan. Neuropsikologi adalah interface neurologi dan neurosains, yang dipacu oleh kemajuan yang sangat pesat dalam penelitian biokimia, ilmu faal, histologi susunan syaraf pusat. Neuropsikolog atau neurologi berasumsi bahwa perilaku manusia, kepribadiannya, proses psikopatologi dan strategi kognitif diantarai (mediated) oleh otak (Carlson 1992). Neuropsikologi klinis yang bertujuan mendeteksi dan mendiagnosis proses neuropatologi, dan menjembatani gap antara dengan ilmu-ilmu perilaku. Neuropsikologi klinis melakukan evaluasi kekuatan dan kelemahan aspek kognitif, aspek psikologis, serta menentukan hubungannya dengan fungsi otak.

Para ahli neuropsikologi memiliki fungsi dalam sejumlah peran yang berbeda. Peranperan para neurologi adalah,

- Mambantu menegakkan peraturan dalam melakukan diagnosis tertentu

- Membuat prediksi mengenai prognosis maupun penyembuhannya

- Neurologi memiliki peran utama dalam memberikan intervensi dan rehabilitasi.

\section{OTAK : STRUKTUR, FUNGSI, DAN GANGGUAN}

Bagan Skematis Pembagian Otak Manusia

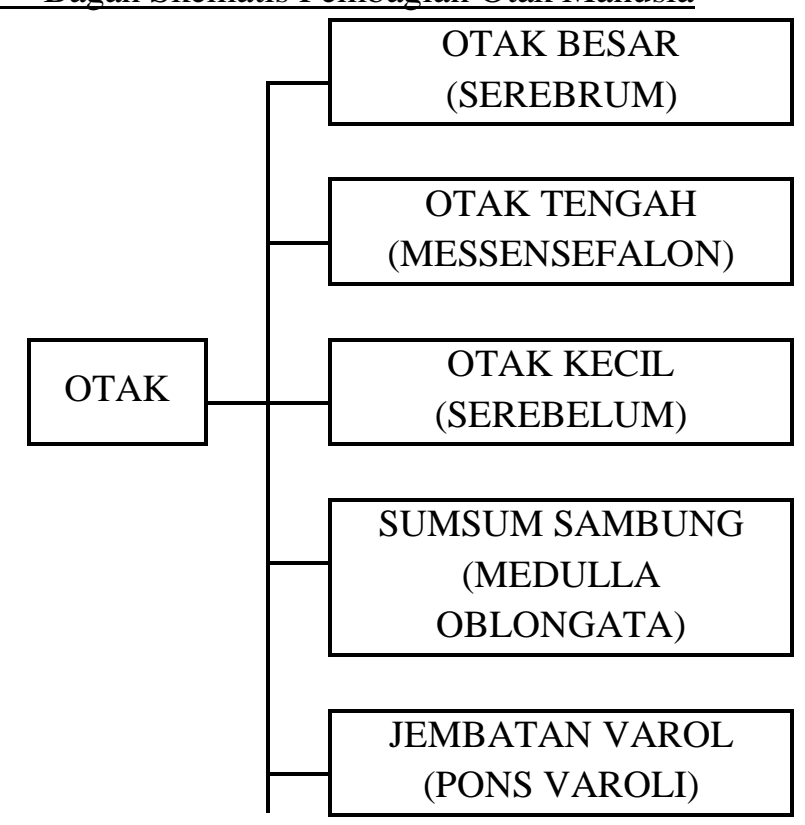


Berat otak kira-kira $\mathbf{2 \%}$ dari berat badan, tapi sekitar $18 \%$ dari volume darah seluruhnya beredar dalam sirkulasi darah otak. Otak juga menggunakan sekitar 20\% dari oksigen yang dihirup melalui paru. Secara anatomi pada korteks selebri terdapat beberapa fisura dan sulkus yang memisahkan lobuslobus frontalis, parietalis, temporalis dan oksipitalis. Lesi pada serebri dapat menimbulkan sindroma kortikal, lesi destruktif (paralitik) mengakibatkan defisit neurologik, sedang iritatif mengakibatkan fenomena positif.

\section{Teori Perkembangan Otak}

Menurut Diana Mutiah (2010: 14), faktor terpenting yang terdapat dalam diri manusia yang akan menentukan perkembangan manusia selanjutnya adalah otak, yaitu keseimbangan otak kiri dan belahan otak kanan. Otak manusia hanya satu yang terdiri dari belahan otak kiri dan belahan otak kanan. Kedua belahan otak itu harus selalu dalam keseimbangan, tetapi kenyataannya tidak seperti itu. Teori perkembangan otak ini berkaitan erat dengan perspektif neuropsikologi, sebab itu peneliti memanfaatkan pula teori perkembangan otak sebagai kajian pustaka.

Selanjutnya menurut Diana Mutiah (2010: 14), fungsi dan struktur otak terkait dengan seluruh kegiatan kita yaitu kegiatan mental, berpikir, emosi, dan memori, di mana semuanya terkait dengan otak. Kalau kita mengerti tentang perkembangan otak kita, maka kita akan mengerti tentang teori perkembangan.

Ketidakpedulian belajar dan kesulitan belajar merupakan bidang yang sangat luas, dan sangat komplek untuk dipelajari, karena menyangkut sekurang-kurangnya aspek psikologis, neurologis, perkembangan otak, pendidikan dan aspek kehidupan sosial anak dalam keluarga/masyarakat. Setiap disiplin ilmu memiliki cara pandang yang berbeda dalam memahami dan menjelaskan fenomena kesulitan belajar yang dialami oleh seorang anak.
Dalam kurikulum pendidikan dijelaskan bahwa kesulitan belajar merupakan terjemahan dari bahasa Inggris "Learning Disability" yang berarti ketidakmampuan belajar. Kata disability diterjemahkan "kesulitan" untuk memberikan kesan optimis bahwa anak sebenarnya masih mampu untuk belajar. Istilah lain learning disability adalah learning difficulities dan learning differences. Ketiga istilah tersebut memiliki nuasnsa pengertian yang berbeda. Di satu pihak, penggunaan istilah learning differences lebih bernada positif, namun di pihak lain istilah learning disabelities lebih menggambarkan kondisi faktualnya. Untuk menghindari bias dan perbedaan rujukan maka yang digunakan istilah kesulitan belajar (Subini, 2012)

Istilah "kesulitan belajar" tidak lepas juga dengan kata Diagnosis. Kata "Diagnosis" berasal dari bahasa Yunani, berarti penentuan jenis penyakit dengan meneliti (memeriksa) gejala-gejala atau proses pemeriksaan terhadap hal yang dipandang tidak beres. Dengan demikian, secara terminologis, diagnosis kesulitan belajar adalah pemeriksaan yang dilakukan oleh guru atau penyuluh terhadap murid yang diduga mengalami kesulitan belajar untuk menentukan jenis dan kekhususan kesulitan belajar (Bustami Said, 2006)

Dari hasil diagnosis ini, guru merancang pertolongan terhadap murid berupa perbaikan belajar-mengajar. Optimalisasi perbaikan belajar-mengajar itu berlangsung dengan baik, apabila usaha guru untuk memperbaiki cara belajar murid adalah seimbang dengan usaha guru untuk memperbaiki acara pengajarannya sendiri. Dan hendaknya juga diingat, agar guru tidak hanya berpikir supaya anak itu mengerti tapi harus mengerti cara anak berpikir. Beberapa peranan penting dari diagnosis dan perbaikan belajar dapat dikemukakan antara lain sebagai berikut:

1. Diagnosis dan perbaikan belajar dapat membantu murid untuk berkembang sesuai dengan kemampuannya. Keberadaan diagnosis dan perbaikan belajar sangat besar artinya bagi peserta 
didik yang mempunyai kemampuan untuk teman-temannya sekelas. Tanpa adanya program tersebut, anak yang kurang mampu akan selamanya tertinggal dari teman-temannya. Anak yang pintar mungkin akan menyalurkan kemampuannya yang berlebihan ke halhal yang negatif.

2. Diagnosis dan perbaikan belajar membuat guru lebih mengenal murid-muridnya. Program ini akan menyadarkan guru akan "keaneka-ragaman" muridnya. Kesadaran ini akan menolong guru untuk lebih memvariasikan kegiatan belajarmengajar yang dikelolanya sehingga setiap murid dalam kelas dapat memetik manfaatnya.

3. Akibat dari kedua hal tersebut, program diagnosis dan perbaikan belajar akan sangat berperan dalam meningkatkan kepuasan guru mengajar dan kepuasan murid belajar. Murid yang belajar dengan kondisi yang memungkinkan dia maju sesuai dengan kecepatannya, akan merasa memiliki suatu kemampuan karena dia dapat menguasai apa yang dipelajarinya.

\section{Dalam US Office of Education dan US} National Joint Committee on Learning Disabilities dinyatakan bahwa istilah kesulitan belajar (Learning Disability) didefinisikan sebagai suatu kelompok gangguan yang bersifat heterogen, dan mengandung karakteristik yang bervariasi antarindividu sehingga mengakibatkan adanya perbedaan antara IQ dengan prestasi yang dicapai anak (J.M., Morris, R. D. Fletcher, \& G.R. Lyon, 2003). Manifestasi dari kesulitan belajar ini berupa hambatan untuk mendengarkan, berbicara, membaca, menulis, berpikir logis, dan kemampuan matematis. Kesulitan belajar tidak selalu eksplisit, sehingga untuk mendeteksi kesulitan belajar anak, akan dilakukan pemeriksaan inteligensi. IQ telah menjadi salah satu kriteria penting untuk menentukan apakah seorang anak mengalami kesulitan belajar atau tidak, yang ditandai dengan tingkat IQ yang berada pada taraf ratarata atau di atas rata-rata.

Menurut Lyon bahwa sebanyak 90\% siswa dengan kesulitan belajar juga mengalami kesulitan membaca (Lyon, G, R . 1996). Di negara berkembang seperti Indonesia, prevalensi siswa dengan kesulitan belajar dimungkinkan lebih besar, mengingat berbagai masalah kesehatan, antara lain tingginya angka kurang gizi pada ibu dan anak, penyakit persalinan, dan penyakit diare, yang menjadi salah satu faktor risiko kesulitan belajar (Pramudigdo, M, 1998). Di samping itu, Indonesia termasuk negara yang memiliki masalah kesulitan belajar membaca. Indeks kemampuan membaca siswa SD di Indonesia jauh berada di bawah indeks Singapura (Kompas, 2008).

Selain itu, kurangnya pemahaman tentang siswa dengan kesulitan belajar memberikan dampak terhadap upaya-upaya pembelajaran yang dilakukan oleh guru dalam rangka meningkatkan prestasi akademik siswa, yang selanjutnya dapat mempengaruhi mutu sekolah. Hal ini disebabkan pada umumnya kesulitan belajar baru terdeteksi saat siswa mulai duduk di bangku sekolah dasar.

\section{PEMBAHASAN}

Syarat memperoleh prestasi yang baik adalah: 1) peserta didik memiliki kemampuan berpikir tinggi yang ditandai dengan berpikir kritis, logis, sistematis dan objektif; 2) Memiliki minat yang tinggi terhadap mata pelajaran; 3) Memiliki bakat dan minat yang dapat dikembangkan sesuai dengan potesinya; 4) Menguasai bahan-bahan dasar yang diperlukan untuk belajar lanjutan; 5) Menguasai salah satu Bahasa asing terutama Bahasa Inggris; 6) Stabilitas psikis; 7) Kesehatan jasmani; 8) Lingkungan yang tenang; 9) Kehidupan ekonomi yang memadai; dan 10) Menguasai teknik belajar di sekolah maupun di luar sekolah.

Inteligensi melibatkan serangkaian kemampuan berpikir yang mempengaruhi siswa dalam mencapai prestasi belajar. Tingkat inteligensi yang tergolong lambat belajar 
ditandai dengan adanya hambatan untuk memproses informasi yang membutuhkan kemampuan analisis sintesis yang cukup kompleks dan membutuhkan tingkat pemahaman yang tinggi terhadap informasi yang diberikan.

Akibatnya siswa mengalami kesulitan dalam belajar. Di samping itu, siswa membutuhkan waktu belajar relatif lebih lama dibandingkan siswa yang memiliki tingkat inteligensi rata-rata. Dari hasil penelitian ini, menunjukkan adanya kesamaan dengan studi yang dilakukan oleh Ames serta Belmont \& Belmont $^{1}$ yang menyatakan bahwa kesulitan belajar dapat terjadi pada semua tingkat IQ. Skor IQ diperkirakan menjadi salah satu tolok ukur sejauh mana pengetahuan dapat diperoleh. $^{2}$ Pembahasan hasil penelitian ini difokuskan pada siswa dengan kesulitan belajar spesifik dan siswa lambat belajar.

\section{Spefisik}

Siswa dengan Kesulitan Belajar

Siswa dengan kemampuan inteligensi rata-rata menunjukkan beberapa ciri anak dengan kesulitan belajar spesifik. Hal ini ditunjukkan melalui hasil skrining guru bahwa siswa yang bersangkutan memiliki kesulitan terkait dengan kemampuan membaca, berhitung, dan menulis. Misal, subjek seringkali kehilangan jejak saat membaca, kesulitan memahami konsep angka dan urutan, serta ketidakkonsistenan dalam penulisan huruf.

Kemampuan membaca dan berbahasa subjek dengan kesulitan belajar spesifik tampak berkembang kurang optimal. Sebagian subjek membutuhkan waktu yang relatif lama untuk membaca dan mengeja kata-kata. Kesulitan ini berkaitan dengan ketidakmampuan pada proses fonologis (inadequate phonological processing abilities) yang ditandai dengan kesalahan membaca kata-kata yang tidak familiar sehingga

1 Kavale, K.A. \& Forness, S. K. 2003. Learning disability as a discipline. In Swanson, H.L., Harris, K.R., \& Graham, S. (Eds). Handbook of Learning Disability (pp. 76-93). New York: The Guilford Press.

2 Gunderson, L., \& Siegel, L.S. (2001). Loc.Cit. mempengaruhi pemahaman terhadap informasi yang dibaca. Kondisi ini sesuai dengan salah satu ciri dari disleksia, yaitu kesulitan memahami isi bacaan sebagaimana yang dikemukakan oleh Turner \& Rack (2005) dan Singleton (2003).

\section{Siswa Lambat Belajar (Slow Learner)}

Siswa lambat belajar ditunjukkan dengan adanya kesulitan menyelesaikan tugas sekolah oleh karena hambatan dalam memproses informasi. Keberadaan siswa lambat belajar merupakan fenomena yang kurang mendapatkan perhatian, sehingga guru dan orang tua tidak menaruh curiga karena ketiadaan perbedaan fisik dibandingkan siswa pada umumnya. Keluhan guru dan orangtua terkait dengan kesulitan siswa dalam menyelesaikan tugas-tugas sekolah, sulit membaca atau menulis atau berhitung, kesulitan mengingat, ketidakmampuan untuk berkonsentrasi, dan hiperaktivitas merupakan karakteristik pada siswa lambat belajar mendukung penelitian yang dilakukan oleh Kaznowski (dalam Kalande dkk, 2008). Selanjutnya, siswa lambat belajar akan mengalami kesulitan terhadap tugas-tugas yang menuntut kemampuan pemecahan masalah. Pada penelitian ini, siswa lambat belajar memiliki skor IQ performansi yang lebih tinggi dibandingkan skor IQ verbal. Hal ini disebabkan adanya kesulitan memproses informasi berupa simbol dan yang bersifat abstrak.

Berkaitan dengan tes membaca, siswa lambat belajar menunjukkan kesulitan untuk mengenali huruf dan bunyi, bahkan mengalami pertukaran saat membaca kata yang bentuk hurufnya hampir sama. Namun demikian, apakah tes membaca ini berhubungan dengan skor IQ tidak terjawab dalam penelitian ini. Kendati demikian, beberapa penelitian menunjukkan ketiadaan hubungan antara skor IQ dengan kemampuan membaca (Siegel, 1988; Gunderson \& Siegel, 2001). Bahkan, siswa dengan skor IQ di bawah 80 tidak selalu menunjukkan kesulitan membaca (Siegel, 1988). 
Hasil penelitian menunjukkan bahwa kesulitan belajar yang dialami oleh siswa tidak sepenuhnya sesuai dengan kriteria yang ditetapkan. Kesulitan belajar yang dipahami oleh guru mengarah pada kegagalan siswa menyelesaikan tugas di sekolah dan bukan kesulitan pada proses kognitif. Selain itu, kondisi siswa yang berasal dari kalangan menengah ke bawah berdampak pada terbatasnya aksesibilitas siswa memperoleh informasi baru. Selain itu, dimungkinkan kurangnya dukungan dan model dari keluarga dapat mempengaruhi motivasi anak untuk belajar. Temuan ini mendukung penelitian yang menunjukkan bahwa sosio-ekonomi keluarga merupakan salah satu faktor penting yang mempengaruhi perkembangan kognitif anak (Jordan \& Levine, 2009 ${ }^{3}$; APA, 2003 ${ }^{4}$; dan Jeong dkk, 20085). Oleh karena itu, dibutuhkan pemahaman faktor sosiodemografis dan pengaruhnya terhadap kondisi siswa yang mengalami kesulitan belajar dan upaya penanganan untuk membantu siswa dengan kesulitan belajar.

\section{SIMPULAN}

Berdasarkan penelitian deskriptif analisis dan studi kepustakaan, dalam penelitian ini ditemukan bahwa factor-faktor yang mempengaruhi kepedulian belajar dan terhadap kegiatan belajar siswa di PAUD PELITA Gunungpuyuh Kota Sukabumi sehingga diduga menjadi penyebab Disfungsi Minimal Otak (DMO) adalah: 1) Ketidak

3 Jordan, N. C., \& Levine, S. C. (2009). Socioeconomic variation, number competence, and mathematics learning difficulties in young children. Developmental Disabilities Research Reviews, 15(1), 60-68.

4 APA. Education and Socioeconomic Status. Diunduh pada tanggal 20 Juli

2017.

http://www.apa.org/pi/ses/resources/publications/factshe eteducation.aspx. .

5 Jeong, Eun Ju., Ki Yong Lee, Seung Hyun Kim, Sang Hyun Sung, Young Choong Kim . 2008. Cognitiveenhancing and antioxidant activities of iridoid glycosides from

Scrophularia buergeriana in scopolamine-treated mice. European Journal of Pharmacology 588 (2008) 78-84. journal homepage: www.el sev ier.com/locate/ejphar. seimbangan aktivitas antara belahan otak kiri dan belahan otak kanan; 2) Vascular accidents, yaitu terjadinya penyumbatan atau pecahnya pembuluh darah otak; 3) Tumor, tumor di otak, gejala yang ditampil kadang-kadang terkesan ringan (sakit kepala, gangguan penglihatan), tapi kalau memang ada, akibatnya dapat fatal; 4) Penyakit degeneratif, yaitu penyakit yang menyebabkan terjadinya kemunduran, misalnya dementia jenis Alzheimer, dan lainlain; 5) Defisiensi nutrisi (kurang gizi); 6) Keracunan, yang dapat menyebabkan seseorang mengigau (delirium). 7). Perkembangan otak siswa yang tidak sehat di antaranya disebabkan tidak berfungsinya aliran darah dan oksigen yang masuk ke dalam darah otak sehingga sangat mempengaruhi perilaku siswa PAUD PELITA, Gunungpuyuh, Kota Sukabumi.

\section{DAFTAR PUSTAKA}

APA. Education and Socioeconomic Status. Diunduh pada tanggal 20 Juli 2017.

Bimo Walgito, Pengantar Psikologi Umum, (Yogjakarta: Andi Offset, 1989).

Bustami Said. 2006. Buku Ajar Prinsipprinsip Pengelolaan Pembelajaran, Pamekasan: STAIN Pamekasan Press.

C.R. Bogdan \& S.J Taylor, Introduction In Qualitataive Research Method, New York, John Wiley and Ink 1993).

Dimyati dan Mudjiono, Belajar dan Pembelajaran, (Jakarta: Rineka Cipta, 2009).

Diana Mutiah, Psikologi Bermain Anak Usia Dini, (Jakarta: Kencana Prenada Media Grup, Cetakan ke-1, Maret 2010).

Fletcher, J.M., Morris, R. D., \& Lyon, G.R. (2003). Classification and definition of learning disability. In Swanson, H.L., Harris, K.R., \& Graham, S. (Eds). Handbook of Learning Disability (pp.30- 56). New York: The Guilford Press.

Gunderson, L., \& Siegel, L.S. (2001). The evils of the use of iq tests to define learning disability in first and second language learners. The Reading Teacher, 55(1), 48-55. 
http://www.apa.org/pi/ses/resources/pub lications/factsheeteducation.aspx.

http://makalahpsikologi.blogspot.com/2 010/09/neuropsikologi-alzheimer.html.

Diakses pada 31 Desember 2018 pukul 11.05 wib.

Jordan, N. C., \& Levine, S. C. (2009). Socioeconomic variation, number competence, and mathematics learning difficulties in young children. Developmental Disabilities Research Reviews, 15(1), 60-68.

Jeong, Eun Ju., Ki Yong Lee, Seung Hyun Kim, Sang Hyun Sung, Young Choong Kim . 2008. Cognitive-enhancing and antioxidant activities of iridoid glycosides from

Scrophularia buergeriana in scopolaminetreated mice. European Journal of Pharmacology 588 (2008) 78-84. journal homepage: www.el sev ier.com/locate/ejphar.

Kavale, K.A. \& Forness, S. K. 2003. Learning disability as a discipline. In Swanson, H.L., Harris, K.R., \& Graham, S. (Eds). Handbook of Learning Disability (pp. 76-93). New York: The Guilford Press.

Lyon, G, R . 1996. Learning disabilities. In E.J. Mash \& RA Barkey (Eds). Child psychopathology (pp.520-586). New York; the Guilford Press.

M. Pramudigdo. (1998). Aspek neuropsikologi pada siswa sekolah dasar dengan prestasi belajar rendah. Tesis. Tidak diterbitkan. Program Pendidikan Dokter Spesialis Bagian Ilmu Penyakit Saraf FK Universitas Diponegoro Semarang.

Nini Subini. 2012. Psikologi Pembelajaran, Yogyakarta: Mentari Pustaka.

Poerwandari, Pendekatan Kualitatif Untuk Penelitian Perilaku Manusia, (Jakarta, Lembaga Pengembangan Sarana Pengukuran dan Pendidikan Psikologi (LPSP3) UI, 2009).

Sagala, Syaiful. Konsep dan Makna Pembelajaran Untuk Memecahkan Problematika Belajar dan Mengajar, (Bandung: Alfabeta, 2006).

Sugiyono, Metode Penelitian Pendidikan Pendekatan Kuantitatif, Kualitatif, dan R\&D, (Bandung: Alfabeta, 2007).
Jordan, N. C., \& Levine, S. C. (2009). Socioeconomic variation, number competence, and mathematics learning difficulties in young children. Developmental Disabilities Research Reviews, 15 (1). 